\title{
ПОНЯТТЯ ТА КЛАСИФІКАЦІЯ ПРАВОВИХ ГАРАНТІЙ ЗАХИСТУ ПРАВ І СВОБОД ВІЙСЬКОВОСЛУЖБОВЦІВ В УКРАЇНІ
}

\author{
КАГЛИНСЬКИЙ Олег Свгенович - провідний науковий співробітник \\ Українського науково-дослідного інституту спеціальної техніки судових експертиз \\ Служби безпеки України \\ ПАВЛЕНКО Вікторія Петрівна - науковий співробітник Українського \\ науково-дослідного інституту спеціальної техніки та судових експертиз Служби \\ безпеки України

\begin{abstract}
У статті проведено дослідження поняття, змісту та класифікациї правових гарантій захисту прав $i$ свобод військовослужбовиів в Україні. В умовах проведення ребормування Збройних сил Украӥни, збройних конбліктів на сході Украӥни, напруженої ситуачиї у світі особливого значення набуває захист прав $і$ свобод війсъковослужбовиів, забезпечення гарантій захисту иих прав. Гарантї захисту прав та свобод військовослужбовців закріплені в нормативних актах держави, міжнародних актах способи, засоби, умови реалізащї військовослужбовиями їхніх прав та свобод. Відповідно до правового статусу війсъковослужбовиів їхні права та свободи вирізняються певними особливостями: по-перше, вони визначаються з урахуванням особливостей війсъкової служби й війсъкового законодавства; по-друге, права та свободи війсъковослужбовців можуть бути обмежені в окремих випадках, які передбачені внутрішнім законодавством, міжнародними актами та законодавством інших країн (наприклад, у здійсненні війсъкової допомоги в рамках міжнародного співробітництва); по-трете, права та свободи військовослужбовиів мають відповідати особливим інтересам держави у сфері безпеки й оборони, інтересам війсъкової служби тощо. Гарантї захисту прав та свобод війсъковослужбовців можна класибікувати залежно від того, які саме права та свободи можуть бути реалізовані за допомогою иих гарантій. У статті підтримується висловлена в науці думка щодо класибікащиї гарантій захисту прав та свобод війсъковослужбовців на політичні, сочіальні, економічні, юридичні,
\end{abstract}

духовні, юридичні тощо. Враховуючи обмежений обсяг дослідження, у статті було розглянуто політичні, економічні й сочіальні гарантї захисту прав та свобод військовослужбовиів, виокремлено труднощі в їхній реалізащиї.

Ключові слова: військовослужбовиі, гарантї, захист прав, економічні гарантї, політичні гарантї, сочіальні гарантї, права, свободи.

\section{Вступ}

Збройний конфлікт на сході України, напружена ситуація у світі спричинили здійснення реформування Збройних сил України. В умовах його проведення особливого значення набуває захист прав i свобод військовослужбовців, забезпечення гарантій захисту цих прав. Ці питання актуальні в багатьох галузях права: конституційному, адміністративному, цивільному тощо. Відповідно до ч. 2 ст. 3 Конституції України, права і свободи людини та їхні гарантії визначають зміст i спрямованість діяльності держави, а їхн утвердження й забезпечення $є$ головним обов'язком держави [1]. У ст. 16 Закону України «Про Збройні Сили України» законодавець конкретизує положення Основного Закону й визначає, що "держава забезпечує соціальний і правовий захист військовослужбовців, резервістів, які виконують обов'язки служби у військовому резерві, та військовозобов'язаних, призваних на навчальні (або перевірочні) та спе- 
ціальні збори, членів їх сімей, працівників Збройних Сил України, а також членів сімей військовослужбовців, резервістів та військовозобов'язаних, які загинули (померли), пропали безвісти, стали особами з інвалідністю під час виконання службових обов'язків або постраждали у полоні в ході бойових дій (війни), в умовах надзвичайного стану чи під час виконання службових обов'язків за межами України в порядку військового співробітництва або у складі національного контингенту чи національного персоналу у міжнародних операціях з підтримання миру і безпеки» [2]. Наведені законодавчі положення, а також реалії сучасного світу підтверджують актуальність обраної тематики для дослідження та спонукають на нові наукові пошуки.

\section{Аналіз останніх досліджень і публікацій}

Основна проблема полягає в тому, що вчені здебільшого досліджують гарантії захисту прав і свобод особи загалом, не виділяючи при цьому особливий статус військовослужбовців. Так, І. Й. Магновський у своїй дисертаційній роботі «Гарантії прав і свобод людини і громадянина в праві України (теоретико-правовий аспект)» здійснив теоретичне дослідження саме гарантії прав і свобод людини і громадянина в Україні загалом, без виділення спеціального статусу окремої категорії осіб - військовослужбовців [3]. Конституційно-правові аспекти забезпечення прав, свобод і обов'язків військовослужбовців в Україні вивчали: $\lambda$. П. Медвідь [4] та В. Й. Пашинський [5]. Адміністративно-правове регулювання політичних прав військовослужбовців Збройних сил України здійснили В. В.Забарський [6], А. М. Синиця [7] та С. П. Пасіка [8]. Соціально-правовий захист військовослужбовців та членів їхніх сімей став предметом розгляду В. І. Кириленка [9]. Одним з останніх досліджень у сфері захисту прав та свобод військовослужбовців стала робота Б. М. Шамрая «Гарантії прав та свобод військовослужбовців в Україні (конституційно-правовий аспект)» [10]. Водночас з урахуванням зміни політичної обстановки у світі вказана про- блематика потребує нового наукового пошуку.

Мета роботи полягає у визначенні поняття та класифікації правових гарантій захисту прав і свобод військовослужбовців в Україні.

\section{Виклад основного матеріалу}

Поняття «гарантії захисту прав і свобод військовослужбовців» нерозривно пов'язано 3 поняттям «гарантії захисту прав особи і громадянина». Останній термін стосується галузі конституційного права, оскільки саме в ній надається визначення основних гарантій захисту прав особи. Захист і повага до прав і свобод людини визначається вченими в галузі конституційного права і теорії держави та права як один зі складників верховенства права. Так, «природні, невід'ємні та невідчужувані права і свободи людини набувають вирішального значення у відносинах між нею і державною владою. Права і свободи особи, - наголошував один із творців доктрини верховенства права А. Дайсі, - 6 основою, а не результатом права країни, а правила, що становлять конституційний кодекс, є не джерелом, а наслідком прав особи» [11, с. 361]. На рівні дисертаційних робіт формулюється висновок, що конституційні права та свободи людини і громадянина - це юридично закріплені рівні для всіх людей і гарантовані державою певні можливості, що необхідні для існування та розвитку людини і громадянина [10, с. 72]. Підтримуємо точку зору автора щодо визначення конституційних прав та свобод людини і громадянина, однак додамо, що їхній зміст не тільки юридично закріплює певні можливості, але й створює юридичні гарантії для реалізації цих можливостей, зокрема, мова йде про гарантії захисту прав і свобод особи. Без гарантій права та свободи людини і громадянина перетворюються на своєрідні «заяви про наміри», що не мають ніякої цінності ні для особи, ні для суспільства. Також особливий акцент слід зробити на тому, що права і свободи людини, а також гарантії їхнього захисту визначають 


\section{Теорія, історія держави і права, конституційне право}

рівень реалізації основного принципу демократичних країн - принципу верховенства права. В аспекті проведеного аналізу варто наголосити, що наведені положення повною мірою застосовуються й до визначення прав та свобод військовослужбовців, а також гарантій їхнього захисту. Однак, відповідно до правового статусу військовослужбовців, їхні права та свободи вирізняються певними особливостями: по-перше, вони визначаються з урахуванням особливостей військової служби й військового законодавства; по-друге, права та свободи військовослужбовців можуть бути обмежені в окремих випадках, які передбачені внутрішнім законодавством, міжнародними актами та законодавством інших країн (наприклад, під час здійснення військової допомоги в рамках міжнародного співробітництва); по-трете, права та свободи військовослужбовців мають відповідати особливим інтересам держави у сфеpi безпеки й оборони, інтересам військової служби тощо. Розглянемо це питання більш детально.

Зокрема, В. Й. Пашинський під конституційними правами та свободами військовослужбовців розуміє закріплені в Конституції та гарантовані державою можливості, які дозволяють обирати вид своєї поведінки, користуватися представленими благами для задоволення своїх особистих і суспільних потреб та інтересів особам, які проходять військову службу [5, с. 85]. На думку Б. М. Шамрая, конституційні права та свободи військовослужбовців - це закріплені в Конституції України, законах та інших нормативно-правових актах, гарантовані державою юридичні можливості осіб, які встановлюються для задоволення їхніх особистих і службових потреб та інтересів 3 метою забезпечення розвитку суспільства, держави, інших фізичних та юридичних осіб під час проходження ними військової служби [10, с. 73]. Загалом підтримуємо наведені пропозиції і наголосимо на тому, що в науці загальноприйнятою є думка про те, що права і свободи потрібно не тільки закріплювати на рівні законодавства, але і створювати умови, гарантії їньої реалізації на практиці.
Без належних гарантій вони залишаються правами і свободами на папері.

Якщо із закріпленням прав і свобод військовослужбовців «на папері», тобто у законодавстві, немає проблем, то із гарантіями їхнього захисту виникають певні труднощі. На рівні наукових досліджень відсутня єдність поглядів щодо визначення цього терміна. Так, Л. П. Медвідь визначає гарантії захисту конституційних прав та свобод військовослужбовців як систему умов, способів і засобів, що утворюються і функціюють для належної реалізації, охорони, а в необхідних випадках - захисту прав та свобод військовослужбовців, визначених Конституцією, законодавством України, зокрема військовим законодавством [4, с. 202]. Інші науковці дещо по-іншому трактують це визначення, однак ключовим є те, що майже всі вчені визначають гарантії захисту прав та свобод військовослужбовців через такі терміни, як «умови», «засоби», «способи», за допомогою яких реалізуються права і свободи військовослужбовців. Підбиваючи певний проміжний підсумок, слід зазначити, що, на нашу думку, гарантії захисту прав та свобод військовослужбовців закріплені в нормативних актах держави, міжнародних актах способи, засоби, умови реалізації військовослужбовцями їхніх прав та свобод.

Для повного розкриття тематики гарантій захисту прав і свобод військовослужбовців в Україні, на наш погляд, необхідно розкрити питання класифікації зазначених гарантій, оскільки класифікація має важливе значення для розуміння гарантій, засобів та способів реалізації прав та свобод особами. Також зауважимо, що гарантії захисту прав та свобод військовослужбовців можна розподілити залежно від того, які саме права та свободи можуть бути реалізовані за допомогою цих гарантій. На сьогодні в літературі відсутня єдність точок зору щодо класифікації гарантій захисту прав та свобод особи. Так само вона відсутня і для класифікації гарантій захисту прав і свобод військовослужбовців. Загальноприйнятим є поділ гарантій захисту прав та свобод особи на політичні, 
соціальні, економічні, юридичні, духовні тощо. Більшість науковців, класифікуючи гарантії захисту прав та свобод людини і громадянина, поділяе їх на загальні (або загальносоціальні), до яких належать політичні, економічні, соціальні, духовні, ідеологічні, культурні тощо, та спеціальні правові (юридичні). Військовослужбовець, як і будь-яка інша особа, користується всіма зазначеними гарантіями, однак є певна особливість, що зумовлена специфікою військової служби. Хоча правові (юридичні) гарантії є спеціальними, слід звернути увагу, що фактично саме за допомогою юридичних гарантій відбувається реалізація тих прав і обов'язків, які закріплені в праві України. Через це можемо виокремити таку точку зору, що закріплення юридичних гарантій $\epsilon$ обов'язковою умовою здійснення особою своїх прав та реалізації свобод. Юридичні гарантії є специфічним правовим засобом забезпечення, реалізації, охорони та захисту прав людини і громадянина, першочергового значення вони набувають при практичній реалізації суб'єктивних прав громадян. Тобто юридичні гарантії - це передбачені законом спеціальні засоби практичного забезпечення прав та свобод людини і громадянина [10, с. 75$]$.

Що стосується правових гарантій захисту прав та свобод військовослужбовців, як зазначає В. Й. Пашинський, правові (юридичні) гарантії реалізації прав та свобод військовослужбовців - це сукупність встановлених державою правових норм, правових способів і засобів, за допомогою яких реалізуються, охороняються, захищаються права і свободи особи та поновлюються порушені права [5, с. 168]. Погодимося із наведеним визначенням і додамо, що це не тільки засоби і способи, за допомогою яких реалізуються, охороняються, захищаються права і свободи особи, але й ті, за допомогою яких реалізуються, охороняються, захищаються права і свободи особи, яка проходить військову службу. Таким чином, правові (юридичні) гарантії реалізації прав та свобод військовослужбовців включають у себе і спеціальні гарантії, що пов'язані із проходженням особою військової служби, і гарантії, якими забезпечуються права і свободи будьякої особи. На підтвердження того, що військовослужбовці користуються тими самими правами та гарантіями, як і інші особи, слід навести ст. 1-2 Закону України «Про соціальний і правовий захист військовослужбовців та членів їх сімей», яка має назву «Гарантії соціального і правового захисту військовослужбовців та членів їх сімей». У ній зазначено, що «військовослужбовці користуються всіма правами і свободами людини та громадянина, гарантіями цих прав і свобод, закріпленими в Конституції України та законах України, з урахуванням особливостей, встановлених цим та іншими законами. У зв'язку з особливим характером військової служби, яка пов'язана із захистом Вітчизни, військовослужбовцям надаються визначені законом пільги, гарантії та компенсації» [12].

Пропонуємо розглянути більш детально класифікаційні групи гарантій захисту прав та свобод військовослужбовців. Поперше, політичні гарантії. Слід зазначити, що частина політичних гарантій закріплена в Конституції України. Так, у ст. 36 вказано, що «громадяни України мають право на свободу об'єднання в політичні партії та громадські організації для здійснення й захисту своїх прав і свобод та задоволення політичних, економічних, соціальних, культурних та інших інтересів, за винятком обмежень, встановлених законом в інтересах національної безпеки та громадського порядку, охорони здоров'я населення або захисту прав і свобод інших людей. Політичні партії в Україні сприяють формуванню і вираженню політичної волі громадян, беруть участь у виборах. Членами політичних партій можуть бути лише громадяни України. Обмеження щодо членства у політичних партіях встановлюються тільки цією Конституцією і законами України...» [1]. Останнє речення прямо стосується військовослужбовців. Незважаючи на те, що політичні права гарантуються і військовослужбовцям, на рівні законодавства встановлено обмеження їхніх політичних прав. Мова йде про участь у політичній діяльності, про участь 


\section{Теорія, історія держави і права, конституційне право}

у мітингах, демонстраціях, страйках тощо. Згаданим вище Законом України «Про соціальний і правовий захист військовослужбовців та членів їх сімей» встановлено, що «військовослужбовці мають право створювати свої громадські об'єднання відповідно до законодавства України. Військовослужбовці не можуть бути членами будьяких політичних партій або організацій чи рухів. Організація військовослужбовцями страйків і участь у їх проведенні не допускається» (ч. 5 ст. 5) [12]. Стаття 17 Закону України «Про Збройні Сили України» має назву «Обмеження політичної діяльності у Збройних Силах України» і закріплює такі обмеження: військовослужбовці зупиняють членство у політичних партіях та професійних спілках на період військової служби; військовослужбовці можуть бути членами громадських організацій, за винятком організацій, статутні положення яких суперечать засадам діяльності Збройних Сил України, і можуть брати участь у їх роботі у вільний від обов'язків військової служби час, коли вони вважаються такими, що не виконують обов'язків військової служби [2].

Окрім політичних прав та свобод військовослужбовців та гарантій їхнього захисту, окрему групу гарантій становлять економічні. Їхнє значення, безумовно, зростає в умовах ринкової економіки, вони $є$ необхідною передумовою матеріального забезпечення особи, яка виконує свої професійні обов’язки. Держава гарантує військовослужбовцям достатне матеріальне, грошове та інші види забезпечення в обсязі, що відповідає умовам військової служби, стимулює закріплення кваліфікованих військових кадрів (ч. 1 ст. 9 Закону України «Про соціальний і правовий захист військовослужбовців та членів їх сімей») [12]. Обмежений обсяг дослідження не дозволяє більш детально розглянути зміст економічних гарантій. Зазначимо лише, що законодавець наділяє громадян широким колом економічних прав, проте військовослужбовці в силу особливостей своєї професійної діяльності обмежені у їхньому здійсненні. Наприклад, військовослужбовцям заборонено займатися під- приємницькою діяльністю. Зазначимо, що в науці пропонується внести зміни до законодавчих положень і закріпити, що «військовослужбовцям, крім військовослужбовців строкової військової служби, у вільний від виконання військових обов'язків час дозволяється займатись додатковою оплачуваною діяльністю 3 урахуванням обмежень, передбачених Законом України «Про запобігання корупції» [10, с. 93].

Окремою групою гарантій захисту прав та свобод військовослужбовців 6 соціальні гарантії. Вони зумовлені характером покладених на військовослужбовців службових обов'язків у зв'язку з виконанням ними державних функцій. У ст. 17 Конституції України закріплено, що «держава забезпечує соціальний захист громадян України, які перебувають на службі у 3бройних Силах України та в інших військових формуваннях, а також членів їхніх сімей» [1]. Соціальними гарантіями є гарантії, які закріплені в законодавстві, умови, засоби, способи, за допомогою яких реалізуються соціальні права військовослужбовців, зокрема право на відпустки, право на охорону здоров' я та медичну допомогу, право військовослужбовців та членів їхніх сімей на освіту тощо.

\section{Висновки}

Обсяг наукової статті не дозволяє здійснити глибоке дослідження щодо визначення поняття та класифікації правових гарантій захисту прав і свобод військовослужбовців в Україні. Окремі аспекти окресленої проблематики стануть предметом подальших наукових пошуків. Наразі проведене дослідження надає можливість зробити такі висновки. В умовах проведення реформування Збройних сил України, збройних конфліктів на сході України, напруженої ситуації у світі особливого значення набуває захист прав і свобод військовослужбовців, створення гарантій захисту цих прав. Гарантії захисту прав та свобод військовослужбовців закріплені в нормативних актах держави, міжнародних актах способи, засоби, умови реалізації військовослужбовцями їхніх прав та свобод. Відповідно до правового статусу 
військовослужбовців, їхні права та свободи вирізняються певними особливостями: по-перше, вони визначаються з урахуванням особливостей військової служби й військового законодавства; по-друге, права та свободи військовослужбовців можуть бути обмежені в окремих випадках, які передбачені внутрішнім законодавством, міжнародними актами та законодавством інших країн (наприклад, під час здійснення військової допомоги в рамках міжнародного співробітництва); по-третє, права та свободи військовослужбовців мають відповідати особливим інтересам держави у сфері безпеки й оборони, інтересам військової служби тощо. Гарантії захисту прав та свобод військовослужбовців можна класифікувати залежно від того, які саме права та свободи можуть бути реалізовані за допомогою цих гарантій. Ми вважаємо слушною класифікацію гарантій захисту прав та свобод військовослужбовців на політичні, соціальні, економічні, юридичні, духовні, юридичні тощо. Враховуючи обмежений обсяг дослідження, у статті було розглянуто політичні, економічні й соціальні гарантії захисту прав та свобод військовослужбовців, виокремлено труднощі в їхній реалізації.

\section{Мiтература}

1. Конституція України. Відомості Верховної Ради України. 1996. № 30, Ст. 141.

2. Про Збройні Сили України: Закон України. Відомості Верховної Ради України. 1992. № 9. Ст.108.

3. Магновський І. Й. Гарантії прав і свобод людини і громадянина в праві України (теоретико-правовий аспект): дис. ... канд. юрид. наук: 12.00.01. Київ, 2003. 221 с.

4. Медвідь $\curlywedge$. П. Права, свободи та обов'язки військовослужбовців в Україні: конституційно-правові аспекти: дис. ... канд. юрид. наук: 12.00.02. Київ, 2016. 249 с.

5. Пашинський В. Й. Конституційноправовий статус військовослужбовців в Україні: дис. ... канд. юрид.наук: 12.00.02. Київ, 2007. 205 с.

6. Забарський В. В. Адміністративноправове регулювання політичних прав військовослужбовців Збройних Сил Укра- їни: автореф. дис. ... канд. юрид. наук: спец. 12.00.07 «Конституційне право; муніципальне право» / Національний авіаційний університет. Київ, 2012. 16 с

7. Синиця А. М. Адміністративно-правове регулювання у сфері забезпечення прав і свобод військовослужбовців: дис. ... канд. юрид. наук: 12.00.07. Харків, 2012. $220 \mathrm{c}$.

8. Пасіка С. П. Адміністративно-правове регулювання соціального забезпечення військовослужбовців Збройних Сил України: автореф. дис. ... канд. юрид. наук: спец. 12.00.07 «Адміністративне право і процес; фінансове право». Запоріжжя, 2011. 20 с

9. Кириленко В. I. Соціально-правовий захист військовослужбовців та членів їх сімей. Основи законодавства України: підручник / за заг. ред. В.І. Кириленка.Вінниця: Нова книга, 2002. С. 280-321.

10. Шамрай Б.М. «Гарантії прав та свобод військовослужбовців в Україні (конституційно-правовий аспект): дис. ... канд. юрид. наук: 12.00.02. Київ, 2018. 238 с.

11. Загальна теорія права: підручник / За заг. ред.. М.І. Козюбри. Київ: Ваіте, 2016. 392 c.

12. Про соціальний і правовий захист військовослужбовців та членів їх сімей: Закон України від 20.12.1991 № 2011-XII. Biдомості Верховной Ради Украйни. 1992. № 15. Cт.190.

Kahlynskyi Oleh Leading Researcher Ukrainian Research Institute of Special Equipment and Forensic Science of the Security Service of Ukraine

Pavlenko Viktoriia Leading Researcher Ukrainian Research Institute of Special Equipment and Forensic Science of the Security Service of Ukraine

THE CONCEPT AND GLASSIFICATION OF LEGAL GUARANTEES FOR THE PROTECTION OF THE RIGHTS AND FREEDOMS OF SERVICEMEN IN UKRAINE

The study of the concept, content and classification of legal guarantees for the protection of the rights and freedoms of servicemen in Ukraine allowed drawing the follow- 


\section{Теорія, історія держави і права, конституційне право}

ing conclusions. In the context of reforming the Armed Forces of Ukraine, armed conflicts in eastern Ukraine, and the tense situation in the world, the protection of the rights and freedoms of servicemen and the provision of guarantees for the protection of these rights are of particular importance. Guarantees of protection of the rights and freedoms of servicemen are the ways, means, conditions of exercise by servicemen of their rights and freedoms enshrined in the regulatory acts of the state, international acts. According to the legal status of servicemen, their rights and freedoms are distinguished by certain features. First, they are determined taking into account the peculiarities of military service and military legislation. Second, the rights and freedoms of servicemen may be restricted in certain cases provided for by domestic law, international acts and the legislation of other countries (for example, in the provision of military assistance in the framework of international cooperation). Third, the rights and freedoms of servicemen must meet the special interests of the state in the field of security and defence, the interests of military service, and so on. Guarantees for the protection of the rights and freedoms of servicemen can be classified according to which rights and freedoms can be exercised through these guarantees. The article supports the opinion expressed by scholars on the classification of guarantees for the protection of the rights and freedoms of servicemen into political, social, economic, legal, spiritual, legal, etc. Given the limited scope of the study, the article considered the political, economic and social guarantees of protection of the rights and freedoms of servicemen, covered the difficulties in their exercise.

Key words: servicemen, guarantees, protection of rights, economic guarantees, political guarantees, social guarantees, rights, freedoms. 